\title{
Leptin Activates Human B Cells to Secrete TNF- $\alpha$, IL-6, and IL-10 via JAK2/STAT3 and p38MAPK/ERK1/2 Signaling Pathway
}

\author{
Sudhanshu Agrawal • Sastry Gollapudi • Houfen Su • \\ Sudhir Gupta
}

Received: 14 December 2010 / Accepted: 30 December 2010 / Published online: 18 January 2011

(C) The Author(s) 2011. This article is published with open access at SpringerLink.com

\begin{abstract}
Leptin, one of the adipokines, functions as a hormone and a cytokine. In this investigation, we show for the first time that leptin, in a concentration-dependent manner, activates human peripheral blood $\mathrm{B}$ cells to induce secretion of IL-6, IL-10, and TNF- $\alpha$. Leptin increased B cells expressing CD25 and HLA-DR. Leptin induces phosphorylation of Janus activation kinase 2 (JAK2), signal transducer and activator of transcription 3 (STAT3), p38 mitogen-activated protein kinase (p38MAPK), and extracellular signal-regulated kinase (ERK1/2). Furthermore, leptin-induced cytokine secretion by $\mathrm{B}$ cells was blocked by inhibitors of JAK2, STAT3, p38MAPK, and ERK1/2. These data demonstrate that leptin activates human $\mathrm{B}$ cells to secrete cytokines via activation of JAK2/STAT3 and p38MAPK/ERK1/2 signaling pathways, which may contribute to its inflammatory and immunoregulatory properties.
\end{abstract}

Keywords B cells $\cdot$ cytokines $\cdot$ activation markers

S. Agrawal $\cdot$ S. Gollapudi $\cdot$ H. Su $\cdot$ S. Gupta

Laboratories of Cellular and Molecular Immunology,

Division of Basic and Clinical Immunology,

University of California,

Irvine, CA 92697, USA

S. Gupta $(\bowtie)$

Medical Sci. I, C-248, University of California,

Irvine, CA 92697, USA

e-mail: sgupta@uci.edu

\section{Introduction}

Leptin is a $16-\mathrm{kDa}$ nonglycosylated protein encoded by the obese $(o b)$ gene, which is located on human chromosome 7 and on mouse chromosome 6. Leptin is synthesized primarily by the white adipose tissue [1]. Leptin functions as a hormone and as a cytokine. As a cytokine, it plays an important role in hematopoiesis, angiogenesis, and innate and adaptive immunity [1-5]. Leptin belongs to a family of class I cytokines, which are characterized by a four $\alpha$-helix bundles [6]. Increased secretion of leptin is associated with chronic inflammatory conditions [1]. A role of leptin in inflammation and autoimmunity is supported by the studies in $O b / o b$ mice (leptin deficient). $O b / o b$ mice have reduced secretion of IL- 2 , IFN- $\gamma$, TNF, and IL-18 and increased production of Th2 cytokines (IL-4 and IL-10). Leptin induces inflammatory cytokines by polarizing $\mathrm{Th} 1 \mathrm{response}$ (IFN- $\gamma$ and TNF- $\alpha$ production) and activation of monocyte/ macrophages and dendritic cells [2-7].

In addition to their well-defined role in antibody production, B cells may also regulate immune responses to microbes and participate in inflammation through production of cytokines, chemokines, and growth factors [8-11]. Human B cells have shown to produce cytokines and chemokines, which can be categorized as: (a) proinflammatory cytokines, IL-1, IL-6, TNF- $\alpha$, and LT- $\alpha$; (b) chemokines MIP- $1 \alpha$, MIP$1 \beta$, MCP-1, IP-10, and IL-8; (c) hematopoietic growth factors, GM-CSF, G-CSF, and M-CSF, which are also mediators of inflammation; and (d) immunoregulatory cytokines, such TGF- $\beta$, IL-10, and IL-13 [8, 11]. To the best of our knowledge, this is the first study to demonstrate that leptin activates human B cells to induce secretion of 
inflammatory cytokines IL- 6 and TNF- $\alpha$ and antiinflammatory IL-10. This effect of leptin is mediated via JAK2/STAT3 and p38MAPK/ERK1/2 signaling pathways.

\section{Materials and Methods}

\section{Subjects}

Peripheral blood mononuclear cells (MNCs) were isolated from blood of healthy young subjects by Ficoll-Hypaque density gradient. Protocol was approved by Human Subject Committee of the Institution Review Board of the University of California, Irvine.

\section{Antibodies and Reagents}

The following antihuman immunoglobulins were used: CD19 PercP, CD69 FITC, CD86 PE, HLA-DR PerCP, and CD25 APC, all from BD Parmingen (San Jose, CA). B cell enrichment kit was purchased from Stem cell Technologies (Vancouver, BC, Canada), and recombinant human leptin from PeproTech (Rocky Hill, New Jersey). Inhibitors of p38MAPK (SB203580), ERK 1/2 (U0126), STAT3 (WP1066), and JAK2 (Tyrphostin AG490) were purchased from Calbiochem (Gibbstown, NJ).

\section{Immunophenotyping}

B cells were stained with PerCP-conjugated anti-HLA-DR, APC-conjugated anti-CD25, FITC-conjugated anti-CD69, and PE-conjugated anti-CD86. After staining, cells were washed extensively with phosphate-buffered saline and analyzed. Flow cytometry was performed using FACScalibur (Becton-Dickenson,San Jose, CA) equipped with argon ion laser emitting at $488 \mathrm{~nm}$ (for FITC, PE, and PerCP excitation) and a spatially separate diode laser emitting at $631 \mathrm{~nm}$ (for APC excitation). Forward and side scatters were used to gate and exclude cellular debris. Ten thousand cells were acquired and analyzed using Flowjo software (Treestar, Ashland, OR).

\section{Purification of B cells}

B lymphocytes were purified by immunomagnetic human B cell enrichment kit according to manufacturer's instructions (STEMCELL Technologies, Vancouver, Canada). In brief, peripheral blood mononuclear cells were suspended at no more than $1 \times 10^{8}$ cells $/ \mathrm{ml}$ in PBS containing $2 \%$ FBS. Negative selection cocktail $(100 \mu \mathrm{l} / \mathrm{ml})$ was added and incubated at room temperature for $15 \mathrm{~min}$. Then, the magnetic nanoparticles were added at $50 \mu \mathrm{l} / \mathrm{ml}$ cells and incubated for $10 \mathrm{~min}$. Cells were placed in a $12 \times 75-\mathrm{mm}$ polystyrene tube at a volume of $2.5 \mathrm{ml} /$ tube and placed into the magnet for $5 \mathrm{~min}$. The magnet was inverted, and the supernatant was poured off. The magnetically labeled unwanted cells remain bound inside the original tube. The purity of negatively selected cells was assessed by flow cytometry $(>97 \%)$ as detected by the presence of CD20. Furthermore, during the process of purification, B cells were not activated as determined by the expression of CD80, CD86, HLA-DR, and CD25 (data not shown).

\section{Measurement of Cytokines}

Cytokine secretion was measured by ELISA assay. Purified $\mathrm{B}$ cells were activated by various concentrations of leptin for $24 \mathrm{~h}$. Supernatants were collected and stored at $-20^{\circ} \mathrm{C}$ until assayed for detection of cytokines by ELISA (ELISA kits from BD Pharmingen, San Jose, CA) as per manufacturer's protocol.

\section{Western Blotting}

Purified B cells were incubated in the presence or absence of $50 \mathrm{ng} / \mathrm{ml}$ of leptin for $10 \mathrm{~min}$, and cells were lysed with lysis buffer. Aliquots of cell lysates containing $20 \mu \mathrm{g}$ of total protein were resolved by SDS-PAGE and transferred onto membranes (Millipore, Bedford, MA) by electroblotting. The membranes were blocked for $1 \mathrm{~h}$ at room temperature in TBS-T buffer with 5\% nonfat dried milk and incubated with primary antibodies overnight at $4^{\circ} \mathrm{C}$. The blots were washed three times for 20 min with TBS-T buffer and then incubated with HRP-conjugated secondary antibodies (1:3,000-1:6,000 dilution) for $1 \mathrm{~h}$ at room temperature. After washing three times for $20 \mathrm{~min}$ in TBS-T buffer, blots were developed using enhanced chemiluminescence reagents (ECL, Pierce Biotechnology, Inc., Rockford, IL) and exposed to clear-blue X-Ray film. Actin was used as a loading control. Bands were scanned, and volumes were calculated. Quantification was done by a ratio between STAT-3 or pSTAT-3 and actin, JAK2 or pJAK2 and actin, pp38MAPK or p38MAP and actin, and pERK1/2 or ERK1/2 and actin.

\section{Results}

Leptin Stimulates Human B Cells to Secrete IL-6, TNF- $\alpha$, and IL-10

Since B cells have been shown to secrete proinflammatory cytokines $[8,9,11]$ and leptin induces proinflammatory cytokine secretion from macrophages and Th1 cells [3, 4], we investigated whether leptin would also activate B cells to secrete proinflammatory cytokines. Purified B cells were cultured in the absence or presence of various concen- 
trations of human recombinant leptin $(0,10 \mathrm{ng}, 25 \mathrm{ng}$, $50 \mathrm{ng}$, and $100 \mathrm{ng} / \mathrm{ml}$ ) for $24 \mathrm{~h}$, and supernatants were collected and analyzed by ELISA assay. Leptin, in a concentration-dependent manner, induced significant secretion of both TNF- $\alpha$ (Fig. 1a) and IL-6 (Fig. 1b) $(\mathrm{p}<0.05$ to $<0.01$ ). B cells produced $10-20$ times more IL- 6 than TNF- $\alpha$. Since IL-10 is secreted as a compensatory antiinflammatory cytokine, we also studied the effect of leptin on IL-10 secretion. Figure 1c shows that leptin, in a concentration-dependent manner, induced IL-10 secretion from B cell $(p<0.05)$. However, leptin did not induce secretion of IL-1 $\beta$ (Fig. 1d). Gabay et al. [12] have also observed minimal or no effect of leptin on IL-1 production by macrophages.

Leptin Activates B cells

Leptin activates both Th1 and monocytes and macrophages [3]. Therefore, we investigated whether leptin also activates B
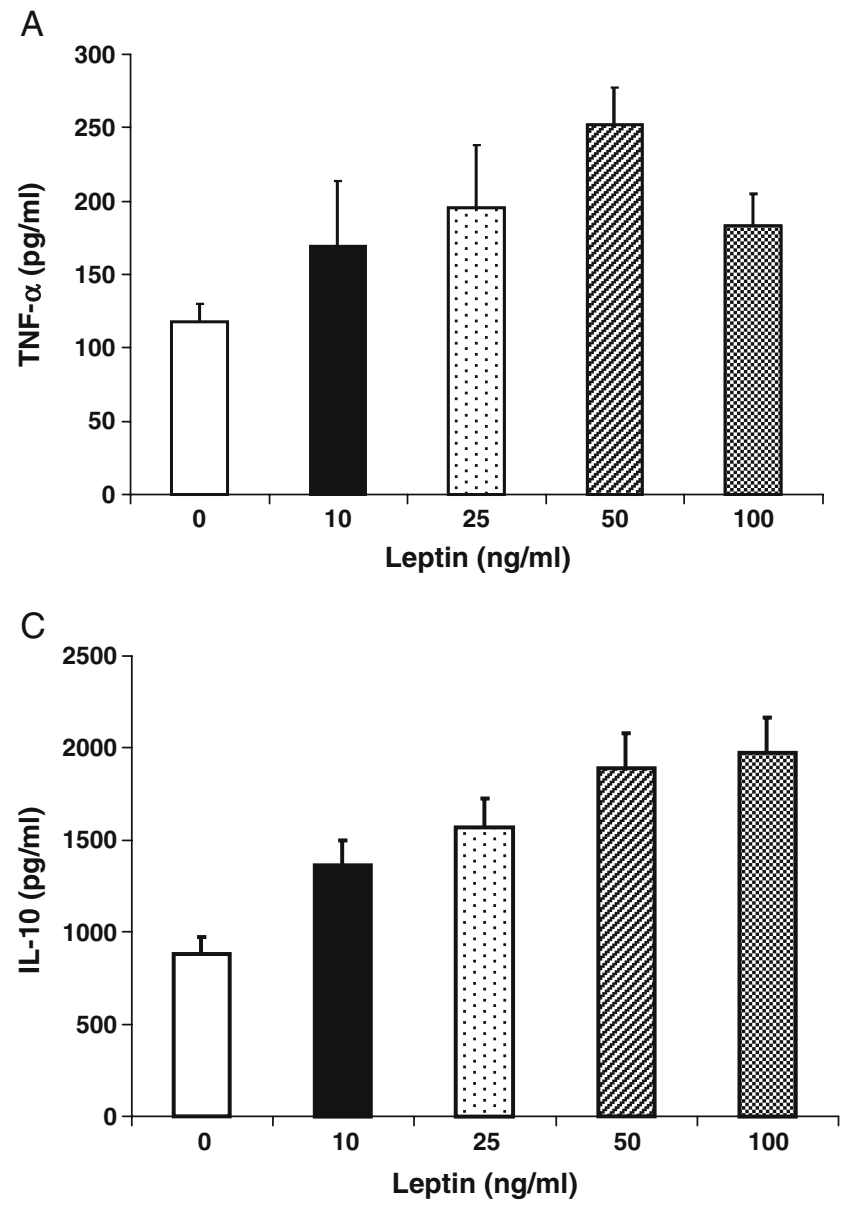

Fig. 1 Leptin stimulates human B cells to secrete IL-6, TNF- $\alpha$, and IL-10. B cells were purified from MNCs from healthy young donors by $\mathrm{B}$ cell enrichment kit and incubated with various concentrations of human recombinant leptin for $24 \mathrm{~h}$, and supernatants were collected cells. Purified B cells were stimulated in the presence or absence of $50 \mathrm{ng} / \mathrm{ml}$ of human recombinant leptin for $24 \mathrm{~h}$. Cells were washed with PBS supplemented with $2 \%$ FBS (PBS/FCS), stained with CD25, CD69, CD86, and HLA-DR antibodies and isotype controls, analyzed for activation markers by multicolor flow cytometry (FACSCalibur) using Flowjo software. Figure 2 shows the data from three different subjects. Leptin increased significantly $(P<0.05)$ proportions of B cells with expression of CD25 and HLA-DR (Fig. 2a). However, no significant difference was observed on the density of any of the activation molecules as determined by mean flourescence intensity (MFI) on B cells (Fig. 2b).

Leptin Activates B cells to Induce Cytokine Secretion via JAK2/STAT3 and p38MAPK/ERK1/2 Signaling Pathways

Since leptin induces intracellular signaling via activation of JAK/STAT, and Ras/Raf signaling pathways [13-22], we examined the effect of leptin on phosphorylation of JAK2,

B

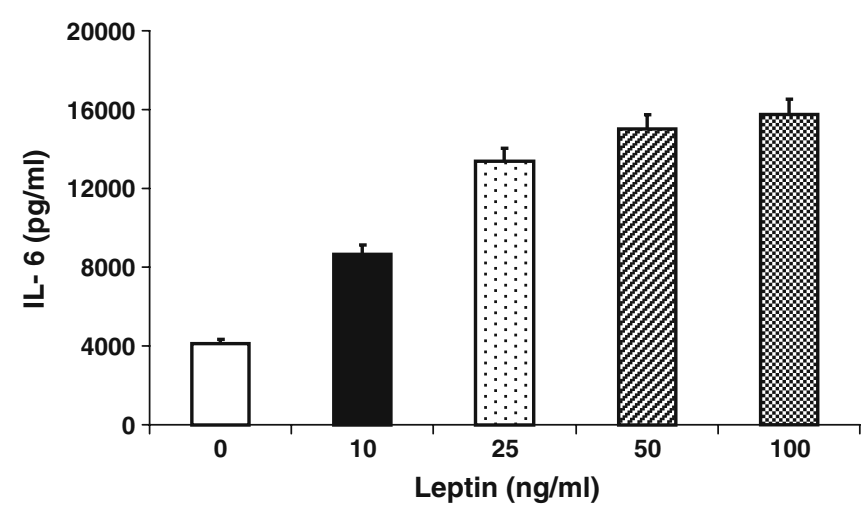

D

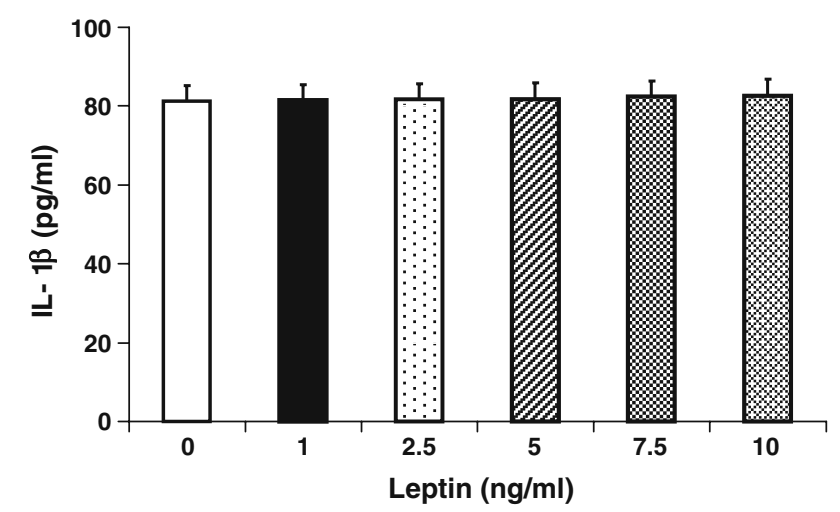

and analyzed by ELISA assay. Figure 1 shows data from three subjects (mean $\pm \mathrm{SD})$. Leptin, in a concentration-dependent manner, induced significant secretion of TNF- $\alpha$ (a), IL-6 (b), and IL-10 (c). Leptin did not induce secretion of IL-1 $\beta$ (d) 

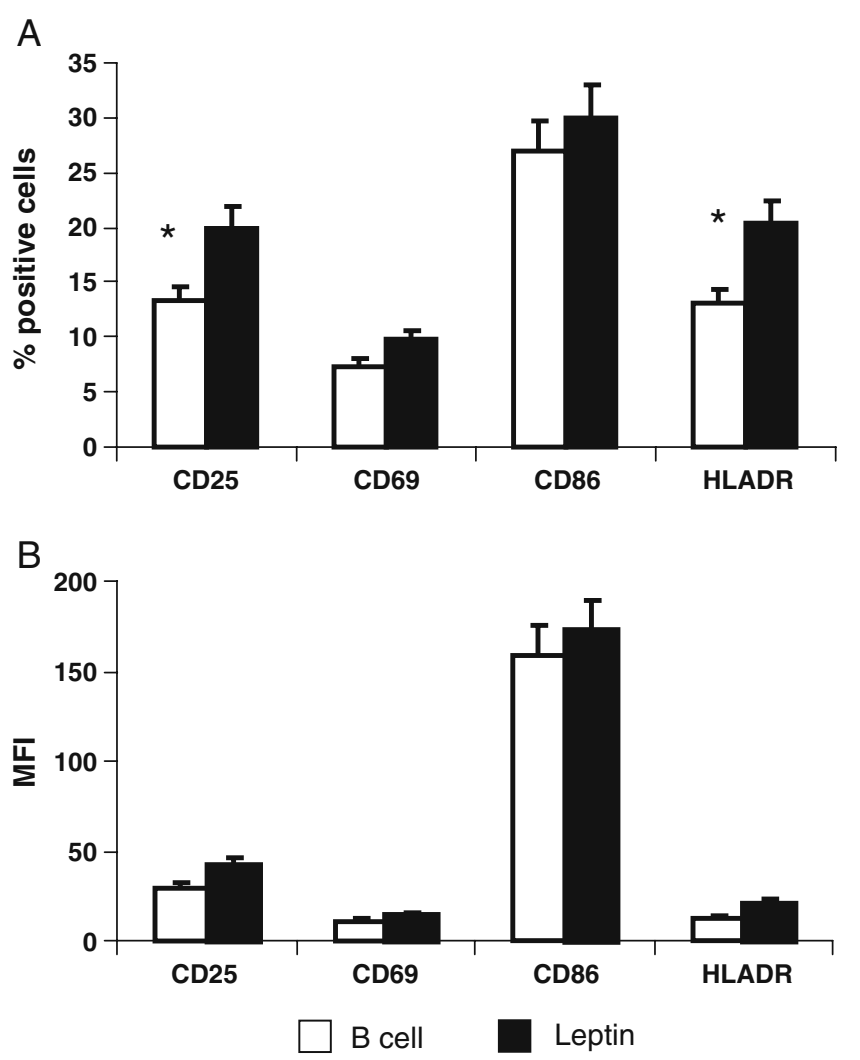

Fig. 2 Leptin activates B cells. Purified B cells were stimulated in the presence or absence of $50 \mathrm{ng} / \mathrm{ml}$ of human recombinant leptin for $24 \mathrm{~h}$, and then stained with CD25, and CD69, CD86, and HLA-DR antibodies and isotype controls, and analyzed by multicolor flow cytometry. Data are from three different subjects. Leptin increased significantly $(* P<0.05)$ proportions of $\mathrm{B}$ cells with expression of CD25 and HLA-DR (a). However, no significant difference was observed on the density of any of the activation molecules as determined by mean flourescence intensity (MFI) on B cells (b)

STAT3, p38MAPK, and ERK1/2. Leptin induced phosphorylation of STAT3 and JAK2 (Fig. 3a), and of p38MAPK and ERK1/2 (Fig. 3b).

To determine a role of JAK2/STAT3 and p38MAPK and ERK1/2 in leptin-induced cytokine production, we examined the effect of inhibitors of JAK2 (Tyrphostin AG490) STAT3 (WP1066), and p38MAPK (SB203580) and of ERK1/2 (U0126) on leptin-induced cytokine secretion. Purified B cells were incubated with $50 \mathrm{ng} / \mathrm{ml}$ of leptin in the presence or absence of inhibitors of JAK2, STAT3, p38MAPK, or ERK1/ 2 for $24 \mathrm{~h}$, and cytokines were measured in the supernatants by ELISA assay. Each inhibitor blocked significantly $(P<$ $0.05-P<0.001)$ leptin-induced secretion of IL-6, TNF- $\alpha$, and IL-10, though to a variable extent (Fig. 4).

\section{Discussion}

Leptin is an adipokine of $16 \mathrm{kDa}$, and in humans, acts as a cytokine, which affects thymic homeostasis and promotes
Th1 cytokine secretion and cytokine production $[1,2,23]$. It appears to play a role in inflammation and autoimmunity [1]. The leptin receptor $(\mathrm{Ob}-\mathrm{R})$ is a member of the class I cytokine receptor family [5, 16, 17, 24], and its mRNA is alternately spliced resulting in at least six isoforms. All isoforms share an identical extracellular ligand-binding domain. However, only the long form (Ob-Rb) appears to be important in leptin signaling. The $\mathrm{Ob}-\mathrm{Rb}$ is expressed in the cells of innate and adaptive immunity [7, 25-28]. Effects of leptin on T cells and antigen-presenting monocytes/ macrophages and dendritic cells have been investigated $[2,7$, 13, 24, 27, 29]; however, effects of leptin on B cells have not been investigated in detail. In this investigation, we report that leptin, in a concentration-dependent manner, activates human $\mathrm{B}$ cells to increased production of proinflammatory IL- 6 and TNF- $\alpha$ and anti-inflammatory IL-10. This is similar to cytokines produced by leptinactivated $\mathrm{T}$ cells and macrophages [1]. However, in B cells, leptin induces tenfold more IL-10 and tenfold less TNF- $\alpha$ as compared to that produced by macrophages. We also show that leptin activates B cells as evidenced by upregulation of CD25 and HLA-DR.

A

\section{Control Leptin actin normalized ratio}

\begin{tabular}{|c|c|c|c|c|}
\hline p-Jak 2 & $=$ & & Control & Leptin \\
\hline Jak 2 & $=$ & p-Jak 2 & 0.43 & 1.25 \\
\hline & & \begin{tabular}{|l|} 
Jak 2 \\
\end{tabular} & 0.25 & 0.23 \\
\hline p-Stat 3 & $\Longrightarrow$ & p-Stat 3 & 0.80 & 1.46 \\
\hline Stat 3 & $\Longrightarrow=$ & Stat 3 & 0.35 & 0.29 \\
\hline B-Actin & 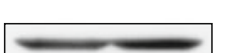 & $\beta$-Actin & 1.00 & 1.00 \\
\hline 3 & Control Leptin & \multicolumn{3}{|c|}{ actin normalized ratio } \\
\hline p-Erk1/2 & -0 & & Control & Leptin \\
\hline \multirow[b]{2}{*}{ Erk1 } & \multirow{2}{*}{-} & P-Erk1/2 & 1.88 & 2.69 \\
\hline & & Erk1/2 & 1.24 & 1.26 \\
\hline p-p38 & -2 & p-p38 & 0.29 & 2.89 \\
\hline p38 & $-\square$ & p38 & 0.49 & 0.44 \\
\hline -Actin & -2 & $\beta$-Actin & 1.00 & 1.00 \\
\hline
\end{tabular}

Fig. 3 Leptin activates B cells via JAK2, STAT3, ERK1/2, and p38MAPK. Purified B cells from young healthy subjects were cultures in the presence or absence of leptin $(50 \mathrm{ng} / \mathrm{ml})$ for $10 \mathrm{~min}$. Cell lysates were prepared, and western blotting was performed using native and phospho anti-JAK2, anti-STAT3, anti-ERK1/2, and anti-p38 MAPK antibodies. Actin was used as a loading control. Bands were scanned, and volumes were calculated by densitometry. Quantification was performed by a ratio between signaling molecule and actin. Leptin induced phosphorylation of JAK2 and STAT3 (a), and of p38 MAPK and ERK1/2 (b) 
Fig. 4 Inhibitors of JAK2/STAT3, p38MAPK, and ERK1/2 inhibit leptin-induced secretion of cytokines. Purified B cells were incubated with $50 \mathrm{ng} / \mathrm{ml}$ of leptin in the presence or absence of inhibitors of ERK1/2 $(12.5 \mu \mathrm{M}$ U0126), JAK2 (25 $\mu \mathrm{M}$

Tyrphostin AG490), STAT3 (WP1066), or p38 MAPK inhibitor (1 $\mu \mathrm{M}$ SB203580) for $24 \mathrm{~h}$, and cytokines were measured in the supernatants by ELISA assay. Each inhibitor significantly blocked leptin-induced secretion of IL-6, TNF- $\alpha$, and IL-10 $(*=P<0.05$, $* * P<0.001)$
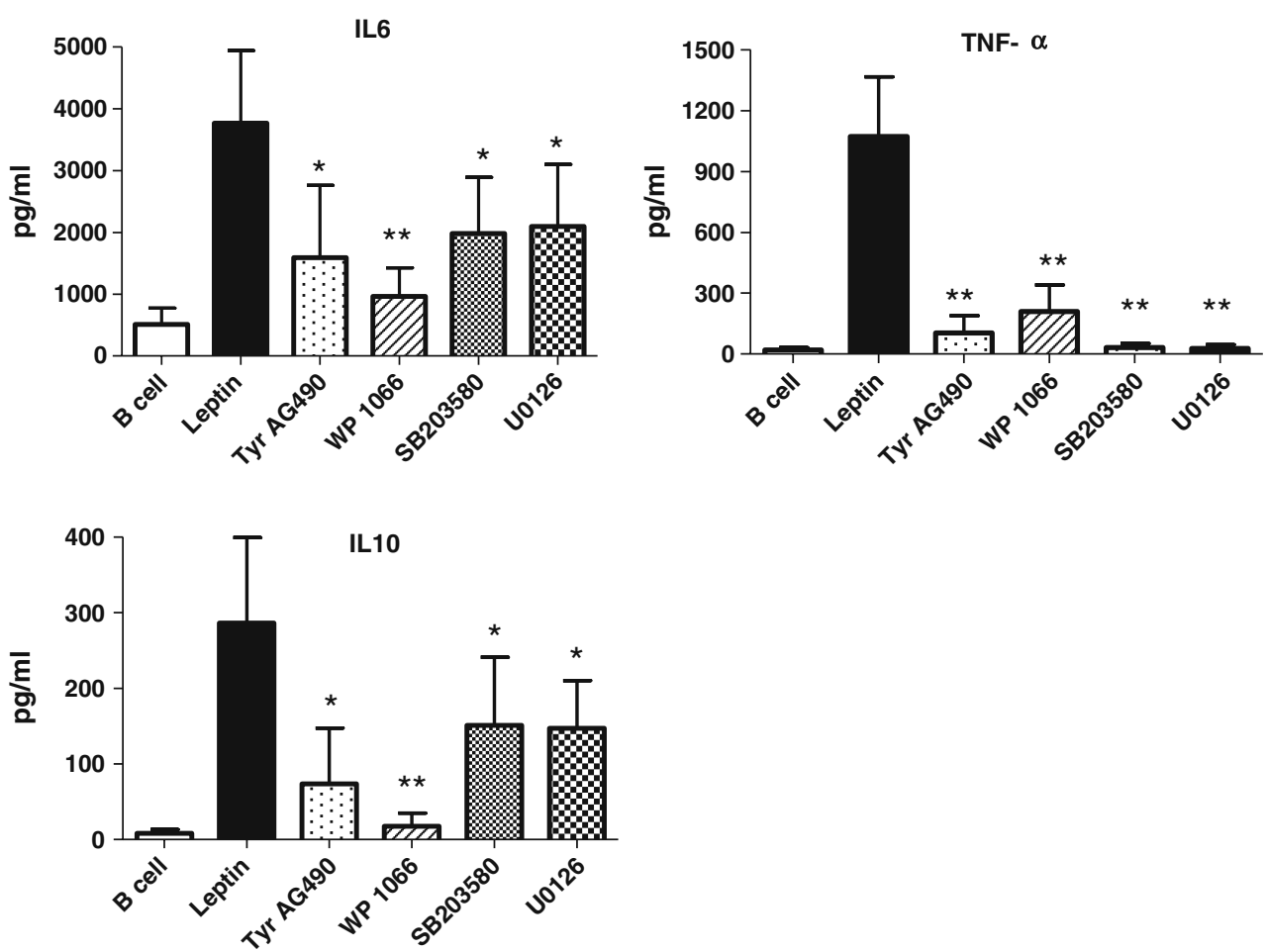

Leptin-induced IL-10 secretion by B cells may also contribute to its immunoregulatory property [18]. Leptin has been reported to polarized T cells toward Th1 type [7]. Recently, it has been reported that leptin activates dendritic cells to secrete IL-12, a cytokine that shifts T cells to Th1 phenotype. It has been reported that IL-12 directly stimulates expression of IL-10 by B cells [30]. Our data show that leptin may directly induce IL-10 secretion from B cells without involvement of IL-12.

The $\mathrm{Ob}-\mathrm{Rb}$ lacks intrinsic tyrosine kinase activity and uses cytoplasmic JAKs for intracellular signaling [18]. There are four known members of JAK family, which are widely expressed except JAK3, which is restricted to hematopoietic cells. However, under physiological conditions, only JAK2 is activated during OB-R signaling [31]. Leptin binding to $\mathrm{Ob}-\mathrm{Rb}$ leads to formation of a receptor complex, allowing activation of JAK2 by auto- or crossphosphorylation. Activated JAK2 then rapidly phosphorylates several tyrosine residues in the cytoplasmic domain of Ob-Rb. Phosphorylated tyrosine 1138 provides a docking site for STAT3 [32]. STAT3 itself is a substrate for JAK2 and homo- or hetero-dimerization upon phosphorylation, translocates to the nucleus, and modulates transcription of genes, including cytokine genes. Our study shows that leptin induces phosphorylation of both JAK2 and STAT3 in purified B cells, and inhibitors of JAK2 (Tyrphostin A940) and STAT3 (WP1066) blocked leptininduced cytokine production, suggesting that leptin induces cytokine production by B cells via JAK2/STAT3 signaling pathway. Similar signaling mechanisms have been observed with activation of mononuclear cells and dendritic cells by leptin $[7,13]$.

Leptin also activates Ras/Raf $[33,34]$ and phosphoinositide 3 kinase (PI3K) pathways [35-37]. SHIP2 activates the MERK pathway including ERK1/2 and p38MAPK through an interaction with the adaptor protein growth factor receptor bound protein 2 (GRB2). Leptin activates monocytes using the MAPK pathway that activates NF-KB [38], and expansion of regulatory $\mathrm{T}$ cells is mediated by ERK1/2 phosphorylation [39]. Leptin enhances TNF- $\alpha$ production in Kuffer cells via p38 and JNK MAPK [19]. Gao et al. [21] have reported leptin-induced activation of cyclooxygenase-2 in endometrial cancer cells via both JAK-2/STAT-3 and MAPK/ERK pathways. Saxena et al. [22] have also reported concomitant activation of the JAK/STAT, PI3K/AKT, and ERK signaling in leptin-mediated promotion of invasion and migration of hepatocellular carcinoma cells. In the present study, we show that leptin induces phosphorylation of ERK1/2 and p38MAPK in purified B cells, and leptininduced cytokine production was blocked by inhibitors of both ERK1/2 and p38MAPK, suggesting that Ras/Raf signaling pathway is involved in leptin-induced cytokine secretion by human B cells.

In summary, leptin activates human B cells to induce synthesis and secretion of cytokines, which is mediated via both JAK-2/STAT3 and MAPK/ERK signaling pathways. Therefore, $\mathrm{B}$ cells in addition to their well-established function in adaptive immunity appear to play a role in innate 
immunity, and leptin via activation of B cells and induction of cytokine secretion may play a role in inflammation and immunoregulation.

Open Access This article is distributed under the terms of the Creative Commons Attribution Noncommercial License which permits any noncommercial use, distribution, and reproduction in any medium, provided the original author(s) and source are credited.

\section{References}

1. La Cava A, Matarese G. The weight of leptin in autoimmunity. Nat Rev Immunol. 2004;4:371-9.

2. Loffreda S, Rai R, Yang SQ, et al. Leptin regulates proinflammatory immune responses. FASEB J. 1998;12:57-65.

3. Santos-Alvarez J, Goberna R, Sanchez-Margalet V. Human leptin stimulates proliferation and activation of human circulating monocytes. Cell Immunol. 1999;194:6-11.

4. Martin-Romero C, Santos-Alvarez J, Governa R, Sanchez-Margalet V. Human leptin enhances activation and proliferation of human circulating T lymphocytes. Cell Immunol. 2000;199:15-24.

5. Matarese G, Moschos S, Mantzoros CS. Leptin in immunology. J Immunol. 2005;174:3137-42.

6. Zhang F et al. Crystal structure of the obese protein leption E-100. Nature. 1997;387:206-8.

7. Mattioli B, Straface E, Quaranta MG, Giordani L, Viora M. Leptin promotes differentiation and survival of human dendritic cells and licenses them for Th1 priming. J Immunol. 2005;174:6820-8.

8. Pistoia V. Production of cytokines by human B cells in health and disease. Immunol Today. 1997;18:343-50.

9. Tumanov AV, Kuprash DV, Mach JA, Nedospasov SA, Chervonsky AV. Lymphotoxin and TNF produced by B cells are dispensable for maintenance of the follicle-associated epithelium bur are required for development of follicles in the Peyer's patches. J Immunol. 2004;173:86-91.

10. Harris DP, Hyanes L, Sayles PC, Duso DK, Eaton SM, Lepak $\mathrm{NM}$, et al. Reciprocal regulation of polarized cytokine production by effector B and T cells. Nat Immunol. 2000;1:475-82.

11. Agrawal S, and Gupta S. TLR1/2, TLR7, and TLR9 signals directly activate human peripheral blood naive and memory B cell subsets to produce cytokines, chemokines, and hematopoietic growth factors. J. Clin. Immunol. 2010 Sep 7. PMID: 20821041 (in press)

12. Gabay C, Dreyer MG, Pellegrinelli N, Chicheportiche R, Meier CA. Leptin directly induces the secretion of interleukin 1 receptor antagonist in human monocytes. J Clin Endocrinol Metab. 2001;86:683-791.

13. Sanchez-Margallet V, Martin-Romero C. Human leptin signaling in human peripheral blood mononuclear cells: activation of the JAK-STAT pathway. Cell Immunol. 2001;211:30-6.

14. Chan JL, Moschos SJ, Bullen J, Heist K, Li X, Kim YB et al. Recombinant methionyl human Leptin activates STAT3 signaling in PBMCs in vivo and regulates soluble TNF- $\alpha$ receptor levels in humans with relative leptin deficiency. J. Clin. Endocr. Metabol. 2005;90:1625-31.

15. Bjorbaek C, Uotani S, da Silva B, Flier J. Divergent signaling capacities of the long and short isoforms of the leptin receptor. J Biol Chem. 1997;272:32686-95.
16. Zabeau L, Defeau D, Van der Heyden J, Iserentant H, Candekerckhove J, Tavernier J. Functional analysis of leptin receptor activation using a Janus kiase/signal transducer and activator of transcription complementation assay. Mol Endocrinol. 2004;18: $150-61$.

17. Leptin receptor (OB-R) oligomerizes with itself but not with its closey relate cytokine signal transducer gp 130. FEBS Lett. 403:7982, 1997

18. Procaccini C, Lourenco EV, Matarese G, La Cava A. Leptin signaling: a key pathway in immune responses. Curr Signal Transduct Ther. 2009;4:22-30.

19. Shen J, Sakaida I, Uchida K, Terai S, Okita K. Leptin enhances TNF-alpha production via p38 and JNK MAPK in LPS-stimulated Kuffer cells. Life Sci. 2005;77:1502-15.

20. Fruhbeck G. Intracellular signaling pathways activated by leptin. Biochem J. 2006;393:7-20.

21. Gao J, Tian J, Lv Y, Shi F, Kong F, Shi H, et al. Leptin induces functional activation of cyclooxygenase-2 through JAK2/STAT3, MAPK/ERK, and PI3K/AKT pathways in human endometrial cancer cells. Cancer Sci. 2009;100(3):389-95.

22. Saxena NK, Sharma D, Ding X, Lin S, Marra F, Merlin D, et al. Concomitant activation of the JAK/STAT, PI3K/AKT, and ERK signaling is involved in leptin-mediated promotion of invasion and migration of hepatocellular carcinoma cells. Cancer Res. 2007;67(6):2497-507.

23. Fantuzzi G, Faggioni R. Leptin in the regulation of immunity, inflammation and hematopoiesis. J Leukoc Biol. 2000;68:437-46.

24. Tartaglia LA. The leptin receptor. J Biol Chem. 1997;272:6093-10.

25. Lord GM, Matarese G, Howard JK, Baker RJ, Bloom SR, Lechler RI. Leptin modulates the T-cell immune response and reverses starvation-induced immunosuppression. Nature. 1998;394:897-901.

26. Zhao Y, Sun R, You L, Gao C, Toan Z. Expression of leptin receptors and response to leptin stimulation of human natural killer cell lines. Biochem Biophys Res Commun. 2002;300:247-52.

27. Sanchez-Margalet V, Martin-Romero C, Santos-Alvarez J, Goberma R, Najib S, Gonzalez-Yanes C. Role of leptin as an immunomodulator of blood mononuclear cells: mechanisms of action. Clin Exp Immunol. 2003;133:11-9.

28. Busso N, So A, Chobaz-Peclat V, Morard C, Martinez-Soria E, Talabot-Ayer D, et al. Leptin signaling deficiency impairs humoral and cellular immune responses and attenuates experimental arthritis. J Immunol. 2002;168:875-82.

29. Lord GM, Matarese G, Howard JK, Bloom SR, and Lechler RL. Leptin inhibits the anti-CD3-driven proliferation of peripheral blood $\mathrm{T}$ cells but enhances the production of proinflammatory cytokines. J. Leuco. Biol. 2002;72:330.

30. Spencer NF, Daynes RA. IL-12 directly stimulates expression of IL-10 by CD5+ B cells and IL- 6 by both CD5+ and CD5- B cells; possible involvement in age-associated cytokine dysregulation. Int Immunol. 1997;9:745-54.

31. Kloek C, Haq AK, Dunn SL, Lavery HJ, Bank AS, Myers MG. Regulation of JAK kinases by intracellular leptin receptor sequences. J Biol Chem. 2002;277:41547-55.

32. Hekerman P, Zeidler J, Bamberg-Lemper S, et al. Peliotropy of leptin receptor signaling is defined by distinct roles of the intracellular tyrosines. FEBS J. 2005;272:109-19.

33. Bjorbaek C, Buchhol RM, Davis SM, et al. The role of SHP-2 in MAPK activation by leptin receptor. J Biol Chem. 2001;276:474755.

34. Takahasi Y, Okimura Y, Mizuno I, et al. Leptin induces mitogenactivated protein kinase-dependent proliferation $\mathrm{C} 3 \mathrm{H} 10 \mathrm{~T} 1 / 2$ cells. J Biol Chem. 1997;272:12897-900. 
35. Keller M, Koch M, Metzinger E, Mushak J, Capp E, Haring HU. Leptin activates PI-3 kinase in $\mathrm{C} 2 \mathrm{C} 12$ myotubes via janus kinase2 (JAK-2) and insulin receptor substrate-2 (IRS-2) dependent pathways. Diabetologia. 1997;40:1358-62.

36. Harvey J, McKay NG, Walker KS, Van der Kaay J, Downes CP, Ashford MLF. Essential role of Phosphoinositide 3-kinase in leptin-induced $\mathrm{K}$ channel activation in the rat CRI-G1 insulinoma cell line. J Biol Chem. 2000;275:4660-9.

37. Martin-Romero C, Sanchez-Margalet V. Human leptin activates P13K and MAPK pathways in human peripheral blood mononu- clear cells. Possible role of Sam68. Cell Immunol. 2001;212:8391.

38. Dreyer MG, Juge-Aubry CE, Gabay C, et al. Leptin activates the promoter of the interleukin-1 receptor antagonist through p42/44 mitogen-activated protein kinase and a composite nuclear factor kappaB/PU. I. Binding site. Biochem J. 2003; 370:591-9.

39. De Rosa V, Orocaccini C, Cai G, Pirozzi G, Fontana S, Zappacosta S, et al. A key role of leptin in the control of regulatory $\mathrm{T}$ cells proliferation. Immunity. 2007;26:241-55. 